\title{
Relationship between sediment conditions and mangrove Rhizophora apiculata seedling growth and nutrient status
}

\author{
Carlos M. Duarte ${ }^{1, *}$, Ole Geertz-Hansen ${ }^{2}$, Udomluck Thampanya ${ }^{3}$, \\ Jorge Terrados ${ }^{1}$, Miguel D. Fortes ${ }^{4}$, Lars Kamp-Nielsen ${ }^{2}$, Jens Borum ${ }^{2}$, \\ Somsak Boromthanarath ${ }^{3}$
}

\footnotetext{
'Centro de Estudios Avanzados de Blanes, CSIC, Camí de Santa Bárbara, s/n, E-17300 Blanes (Girona), Spain

${ }^{2}$ Freshwater Biological Laboratory, University of Copenhagen, Helsingorsgade 51, DK-3400 Hillerod, Denmark

${ }^{3}$ Coastal Resources Institute, Prince of Songkla University, Hat Yai, Songkhla 90112, Thailand

${ }^{4}$ Marine Science Institute, University of The Philippines, Diliman, Quezon City 1101, The Philippines
}

\begin{abstract}
The growth rate and nutritional status of Rhizophora apiculata seedlings were analyzed across mangrove stands with different sediment composition in The Philippines and Southern Thailand. Plant growth differed 10 -fold and the production of new leaves, roots and branches varied between 50 - and 100 -fold across sites. Most (>60\%) of the variance in mangrove growth rate across systems could be accounted for by differences in the nutrient concentration of the leaves, which was in turn related to the interstitial nutrient concentration and the silt plus clay content of the sediments Nutrient-poor coarse sediments were characteristic of mangroves located in the mouths of rivers draining small watersheds, while sediments at the mouths of large rivers had high silt, clay, and nutrient contents, thus allowing the development of nutrient-sufficient, fast-growing $R$. apiculata seedlings. The growth of $R$. apiculata seedlings increased significantly when the plants grew adjacent to rivers draining areas $>10 \mathrm{~km}^{2}$ The results provide evidence that growth of $R$. apiculata seedlings at the edge of the progressing mangrove forests is often nutrient limited, and that the extent of nutrient limitation depends on the delivery of silt and nutrients from the rivers. The coastal zones adjacent to small $\left(<10 \mathrm{~km}^{2}\right)$ drainage areas seem unsuitable to support adequate growth of $R$. apiculata seedlings, and afforestation programmes should, therefore, target mud flats adjacent to large rivers instead.
\end{abstract}

KEY WORDS: SE Asia - Mangrove growth - Nutrient status - Sediment nutrients - Watershed size

\section{INTRODUCTION}

The development of large mangrove forests depends on warm air temperatures, high $(>0.75)$ values of the mean annual rainfall/potential evapotranspiration ratio (Blasco 1984), and the generation of vast intertidal substrata by coastal geomorphic processes (Thom 1984). The climate in Southeast (SE) Asia, which is characterized by high rainfall, and rivers with high silt loads (Milliman \& Meade 1.983, Milliman \& Syvitski 1992) combine to provide favourable conditions for

•E-mail: duarte@ceab.csic.es mangrove development, and mangrove forests cover large areas in the deltaic areas along the coasts of SE Asia (Mcnae 1968). Water hydrology is a major determinant of mangrove productivity, and the highest productivity values are usually reported in mangroves assaciated with rivers (Twilley et al. 1986). River flow and tides are powerful mechanisms for the transfer of matter between ecosystems and they cause a large fraction of mangrove production (on average 29.5\%; Duarte \& Cebrián 1996) to be exported from the ecosystem as leaf litter and propagules (e.g. Twilley et al. 1986, Hemminga et al. 1994, Panapitukkul et al. 1998). In addition, a substantial fraction of the mangrove production is buried in the sediments $(10.4 \%$ on average; 

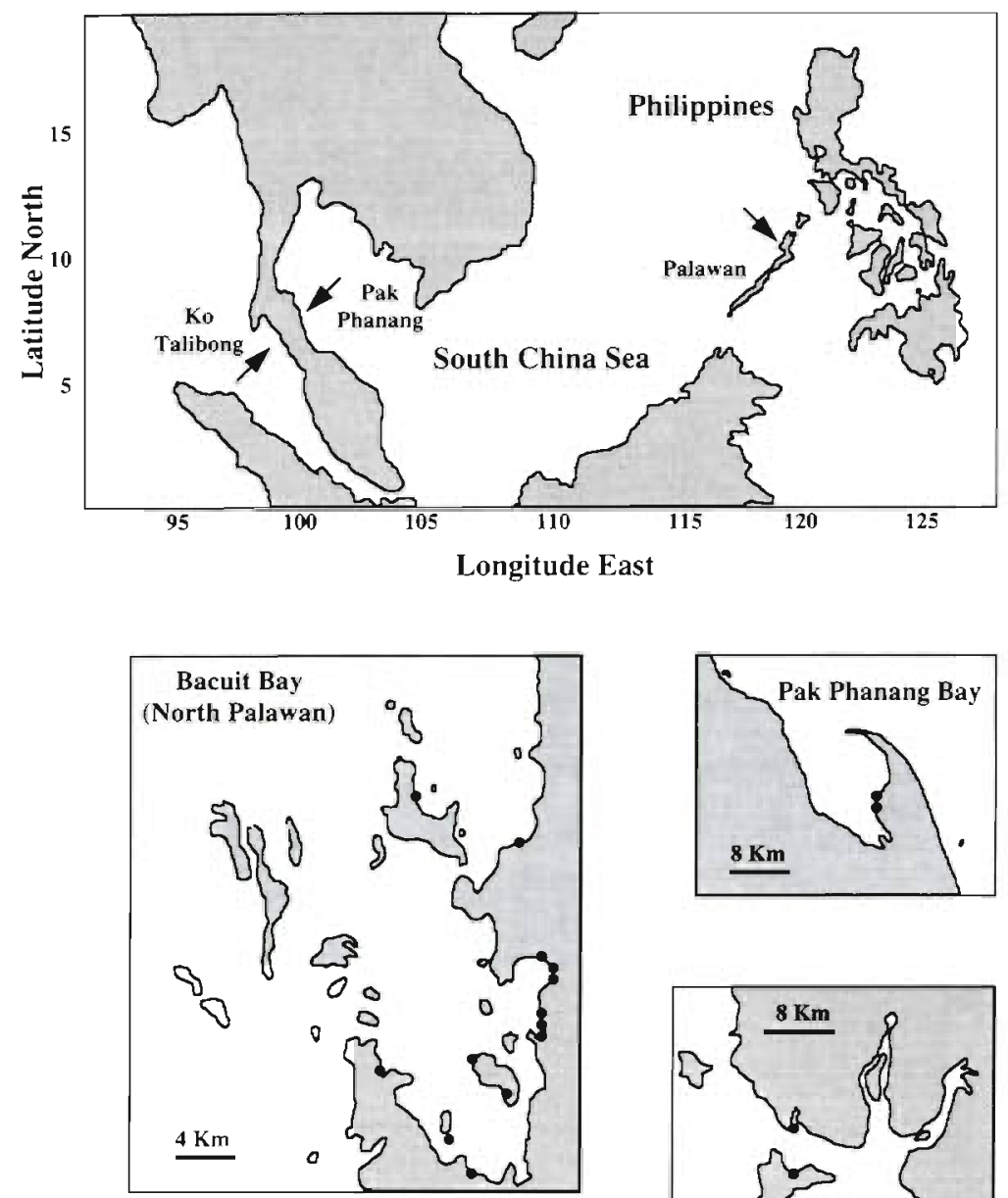

Fig. 1. Study sites and locations ( $\bullet$ ) of the sampling stations

Duarte \& Cebrián 1996), so that the production available for recycling within the ecosystem is reduced (50\% on average; Duarte \& Cebrián 1996). Accordingly, a large fraction of the mangrove production is lost from the ecosystem (Boto \& Bunt 1981, Twilley et al. 1986), leading to an associated high loss of nutrients. Mangrove ecosystems tend to be, therefore, autotrophic communities (Duarte \& Cebrián 1996, Gattuso et al 1998) whose primary production should, therefore, depend on continuous nutrient supply from land or sea.

The continuous export of nutrients from mangrove ecosystems led us to hypothesize that the growth of mangrove trees may often be nutrient limited, as already shown by some nutrient addition experiments (Boto \& Wellington 1983, Feller 1995), and that the extent of nutrient limitation should depend on the input of nutrients from land. Moreover, we suggest that nutrient limitation may be most pronounced at the edge of the mangrove forest, where the higher exposure leads to an increased likelihood of export losses, and where nutrient availability in the sediment is lower (Tam et al. 1995). These considerations suggest that mangrove seedlings established at the edge of the mangrove forest may have reduced growth, which would represent an important bottleneck for the sustained expansion of the mangrove forest (e.g Panapitukkul et al. 1998).

In order to test these hypotheses, we assessed the nutrient ( $C, N$ and $P$ ) status of mangrove seedlings growing along the forest edge across a range of sites in SE Asia. The sites receive discharge from rivers representing a gradient of watershed sizes, which vary from creeks in small islands to large rivers (e.g. Pak Phanang river, Nakhon Si Thamarath, Southern Thailand). In the present study we focused on the seedlings of Rhizophora apiculata, a common species throughout the region, and one that is particularly relevant because of its importance as the target species in afforestation plans (Aksornkoae 1993). Growth of the seedlings was calculated from measurements of height and estimates of age derived from counts of internodes as described by Duke \& Pinzón (1992) for Rhizophora mangle and modified by Duarte et al. (unpubl.) for $R$. apiculata. The nutrient status of the plants was described from the $\mathrm{C}, \mathrm{N}$ and $\mathrm{P}$ content in their leaves (Chapin 1980), while the nutrient availability at the study sites was represented by the nutrient concentrations within the sediments

\section{METHODS}

Study sites. The study was conducted under the framework of a large, interdisciplinary project aimed at elucidating effects of siltation on SE Asian coastal ecosystems (CERDS project, funded by the European Commission). The study extended across sites in The Philippines (Bacuit Bay, Palawan) and Thailand (Trang coast, adjacent to Ko Talibong island, and Pak Phanang estuary), encompassing a broad range of conditions (Fig. 1). Bacuit Bay is a large, open bay with numerous islands of different sizes, which receives freshwater discharges from a couple of medium-sized rivers that support significant mangrove forests at their mouths. Although the Bay is still largely surrounded by forests, the watersheds of the larger rivers are now 
experiencing deforestation and increased erosion resulting from road construction and slash and burn practices, which have led to increased silt loading (Hodgson 1989). In contrast, the islands present in the bay are still almost fully covered by vegetation, and pockets of mangroves grow near the mouth of the small streams and creeks draining the islands.

The coastal areas in Pak Phanang and Trang in Thailand both receive the discharge of large rivers (15 to 120 and 2.5 to $51.5 \mathrm{~m}^{3} \mathrm{~s}^{-1}$, respectively), and mangrove forests develop in the proximity of these river mouths (Fig. 1). The watersheds of both rivers have suffered major changes in land use over the past century, including a recent proliferation of shrimp ponds, which. have led to a major increase in the silt loads of these rivers (CORIN 1991). The Pak Phanang river discharges into a semi-enclosed Bay, where a thick mangrove forest (92 $\mathrm{km}^{2}$; CORIN 1991) progresses at rates of about 40 to $50 \mathrm{~m} \mathrm{Yr}^{-1}$ along the mud flat formed by river deposits (cf. Panapitukkul et al. 1998). Additional details on the sites can be found in Panapitukkul et al. (1998) and Terrados et al. (1998).

Sampling and analyses. Several sampling stations, located along the fringes of mangrove formations in the mouths of rivers of contrasting catchment sizes, were established in March-April 1996 following a preliminary survey conducted in 1995. The mangroves ranged from large forests, associated with large rivers, to small groups of seedlings with a few adult trees growing on the shores of small islands. The size of the watersheds of the different rivers was obtained from national geographic databases and reports. Whenever these estimates were unavailable, the watershed of the rivers was delineated on a topographic map and digitized to estimate the size of the riverine watershed associated with the mangrove stands sampled.

At each sampling site, the height of 30 to 40 Rhizophora apiculata seedlings, spanning the broadest possible range in size ( $<1$ to $3.5 \mathrm{~m}$ ), was recorded, and the number and individual lengths of internodes along the main axis were measured. We also counted the number of roots developed by the plants, the total number of standing leaves and the number of branches. A sample of about 12 fully grown leaves was collected from several of the seedlings examined at each station for subsequent analysis of nutrient contents. Leaf carbon and nitrogen were determined using a Carlo-Erba CHN analyzer, while leaf phosphorus was analyzed as phosphate (Parsons et al. 1984) after Kjeldahl digestion. Duplicate sediment cores $14.5 \mathrm{~cm}$ internal diameter, $25 \mathrm{~cm}$ long) were collected to a sediment depth of about $15 \mathrm{~cm}$ at each site and kept refrigerated until processed within 1 to $3 \mathrm{~h}$. The upper $10 \mathrm{~cm}$ of the cores was transferred to a GF-C fiber glass filter, and 5 to $20 \mathrm{ml}$ of porewater was extracted under vac- uum directly into $20 \mathrm{ml}$ vials and preserved with $100 \mu \mathrm{l}$ of concentrated sulfuric acid until later analysis. After neutralization with sodium hydroxide, the samples were analyzed for dissolved reactive phosphate, ammonium and nitrate on an Alpkem RAF autoanalyzer following standard methods (Parsons et al. 1984). The silt plus clay content of sediments was analyzed by weighing the fraction of a subsample of sediment material dried at $105^{\circ} \mathrm{C}$ for $24 \mathrm{~h}$ which passed through a $63 \mu \mathrm{m}$ screen in a sieve-shaker.

Seedling growth determinations. Seedling age was estimated from counts of the number of internodes and knowledge of the number of internodes produced annually. Duke \& Pinzón (1992) reported that seedling age of the mangrove Rhizophora mangle can be determined from the presence of distinct seasonal changes in the length of the internodes, which was also recently confirmed for SE Asian mangrove species, including $R$, apiculata (Duarte et al. unpubl.). In essence, the sequence of the internodal length is first filtered to remove short (<seasonal) and long (interannual) term variability, respectively. Interannual variability is removed using a low-pass filter (running average of 11 internodes), while sub-seasonal variability was removed by filtering the residuals through a high-pass filter (running average of 3 internodes). The remaining signal has a clear periodicity with period length representing the number of internodes produced in a year (Duarte et al. unpubl.). In the present study, annual internode production was estimated from the examination of $>12$ annual cycles per sampling site, and seedling age was determined as the ratio between the number of internodes produced over the life span of the seedling and the average number produced annually.

The rate of seedling growth was subsequently calculated from linear regression between the height of the seedlings, the number of roots, branches and standing leaves, and their estimated age. The slope of the regression equations represents the centimeters grown and the increment in the number of roots, branches, and standing leaves per year. Whenever examination of the relationships suggested these to be nonlinear we fitted an allometric $\left(y=a x^{\mu}\right)$ model to the height or number of standing roots, branches or leaves $(y)$ and the estimates of age $(x)$ to describe the exponential growth rates $\left(\mu, y^{-1}\right)$. The significance of the relationship between seedling growth and leaf nutrient and sediment properties was tested using linear correlation analyses, for which the data were log-transformed when necessary to comply with the assumptions of the analysis. In a few instances, cores containing porewater samples were damaged during transportation to the laboratory, and the samples were lost, resulting in an uneven number of observations for the different paired statistical analyses conducted. 
Table 1. Mean ( \pm SE) and range of the variables measured or derived in this study

\begin{tabular}{|lccc|}
\hline & $N$ & Minimum-maximum & Mean \pm SE \\
\hline Leaf C (\% DW) & 17 & $36.87-46.15$ & $41.16 \pm 0.59$ \\
Leaf N (\% DW) & 17 & $0.78-1.66$ & $1.05 \pm 0.05$ \\
Leaf P (\% DW) & 17 & $0.057-0.11 .7$ & $0.075 \pm 0.004$ \\
Growth (cm d ${ }^{-1}$ ) & 17 & $0.015-0.15$ & $0.059 \pm 0.010$ \\
Internode production (internodes $\mathrm{yr}^{-1}$ ) & 17 & $5.2-8.9$ & $7.3 \pm 0.2$ \\
Net leaf production (leaves seedling & \\
Branch production (branches d ${ }^{-1}$ ) & 17 & $0.005-0.445$ & $0.062 \pm 0.026$ \\
Root production (roots d ${ }^{-1}$ ) & 17 & $0.0004-0.016$ & $0.004 \pm 0.001$ \\
Allometric coefficient of growth in height & 17 & $0.17-0.71$ & $0.004 \pm 0.001$ \\
Allometric coefficient of leaf production & 17 & $0.42-2.28$ & $0.38 \pm 0.04$ \\
Watershed size $\left(\mathrm{km}^{2}\right)$ & 17 & $0.1-100$ & $0.99 \pm 0.13$ \\
\end{tabular}
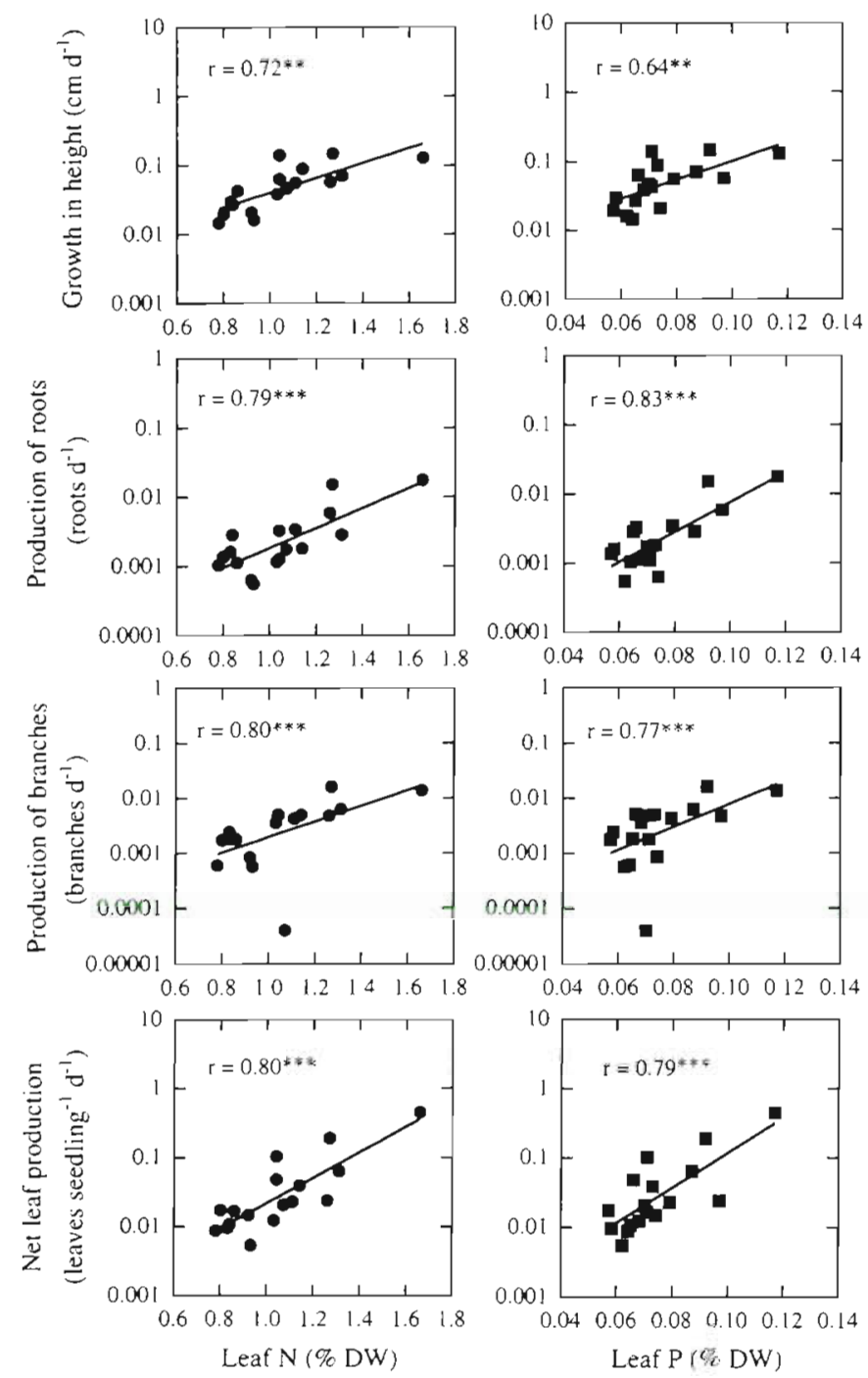

Fig. 2. Rhizophora apiculata. Relationship between the growth rate of mangrove seedlings and the nitrogen and phosphorus concentrations of their leaves (as \% DW). Solid lines represent the fitted regression equations, and $r$ is the corresponding

linear correlation coefficient. $\cdots p<0.01, \cdots p<0.001$

\section{RESULTS}

The number of internodes produced per year did not vary much among mangrove stands and averaged $7.3 \pm 0.2($ mean $\pm \mathrm{SE})$ internodes $\mathrm{yr}^{-1}$ (Table 1$)$. Internode production was independent of sediment conditions and nutrient status of the plants (Pearson linear correlation coefficient, $\mathrm{p}>0.05$ ), suggesting that the number of internodes produced per seedling per year is a rather conservative feature of Rhizophora apiculata. In contrast, the growth rates varied 10 -fold among sites (Table 1), with the fastest growth $\left(0.15 \mathrm{~cm} \mathrm{~d}^{-1}\right)$ recorded for seedlings from the mud flat of the Pak Phanang River and the slowest growth $10.015 \mathrm{~cm} \mathrm{~d}^{-1}$ ) for seedlings growing on the shores of the smaller islands in Bacuit Bay. The relationship between seedling height and age was nonlinear and best described by an allometric relationship. The slope of the allometric relationship averaged $0.38 \pm 0.04$, indicating seedling height to increase as the third power of age (Table 1). The seedlings produced, on average, 1 new stilt root and a new branch every $250 \mathrm{~d}$ but with considerable differences among stands (Table 1). The canopy of the seedlings increased with age, with the plants gaining a new leaf every $2 \mathrm{wk}$, on average. The canopy of seedlings growing on the shores of small islands only gained d new leaf every $200 \mathrm{~d}$, because of high leaf loss rate, while that of seedlings growing on the rich mud flat of the Pak Phanang gained a new leaf every other day (Table 1), as a result of extensive branching and longer leaf life spans.

The nitrogen content of Rhizophora apiculata leaves varied from 0.78 to $1.66 \%$ of dry weight (DW) (Table 1 ). The phosphorus concentration in leaves ranged from 0.057 to $0.117 \%$ of DW and was significantly correlated to foliar nitrogen content $(r=0.93, p<0.001)$. In general, $R$. apiculata seedlings had rather balanced $N$ : $P$ ratios (31.2 \pm 0.6 atomic ratio). The ratio of total inorganic nitrogen (TIN) to phosphate in the sediment porewaters 

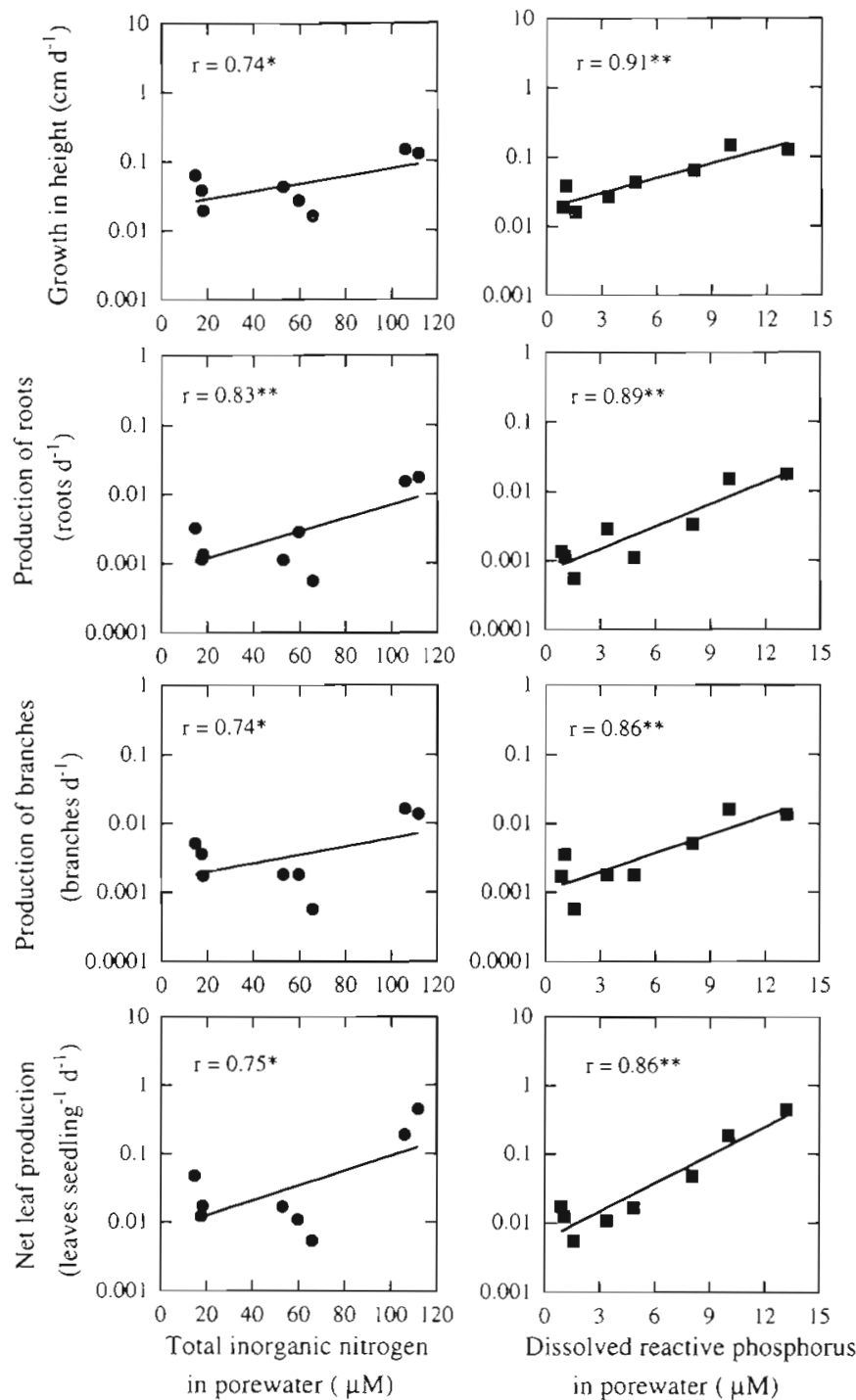

Fig. 3. Rhizophora apiculata. Relationship between the growth rate of mangrove seedlings and the total inorganic nitrogen and dissolved reactive phosphorus concentrations in the sediment porewaters. Solid lines represent the fitted regression equations, and $r$ is the corresponding linear correlation coefficient. $\cdot p<0.05, \cdots p<0.01, \cdots p<0.001$

was relatively low (molar N:P ratio $=7.2 \pm 1.3$ ), suggesting a deficit in nitrogen availability relative to that of phosphorus in the sediment porewaters.

The hypothesis that Rhizophora apiculata growth may be nutrient limited in the area was supported by the finding of strong positive correlations between seedling elongation rate, leaf, root and branch formation and leaf $N$ concentrations $(r \geq 0.72, p>0.005$; Fig. 2 ). Seedling growth was also positively correlated with leaf $\mathrm{P}$ concentrations ( $r \geq 0.64, p>0.005$; Fig. 2). Nutrient concentrations in the leaves were, in turn, associated with the porewater inorganic nutrient concentrations $(r=0.72$
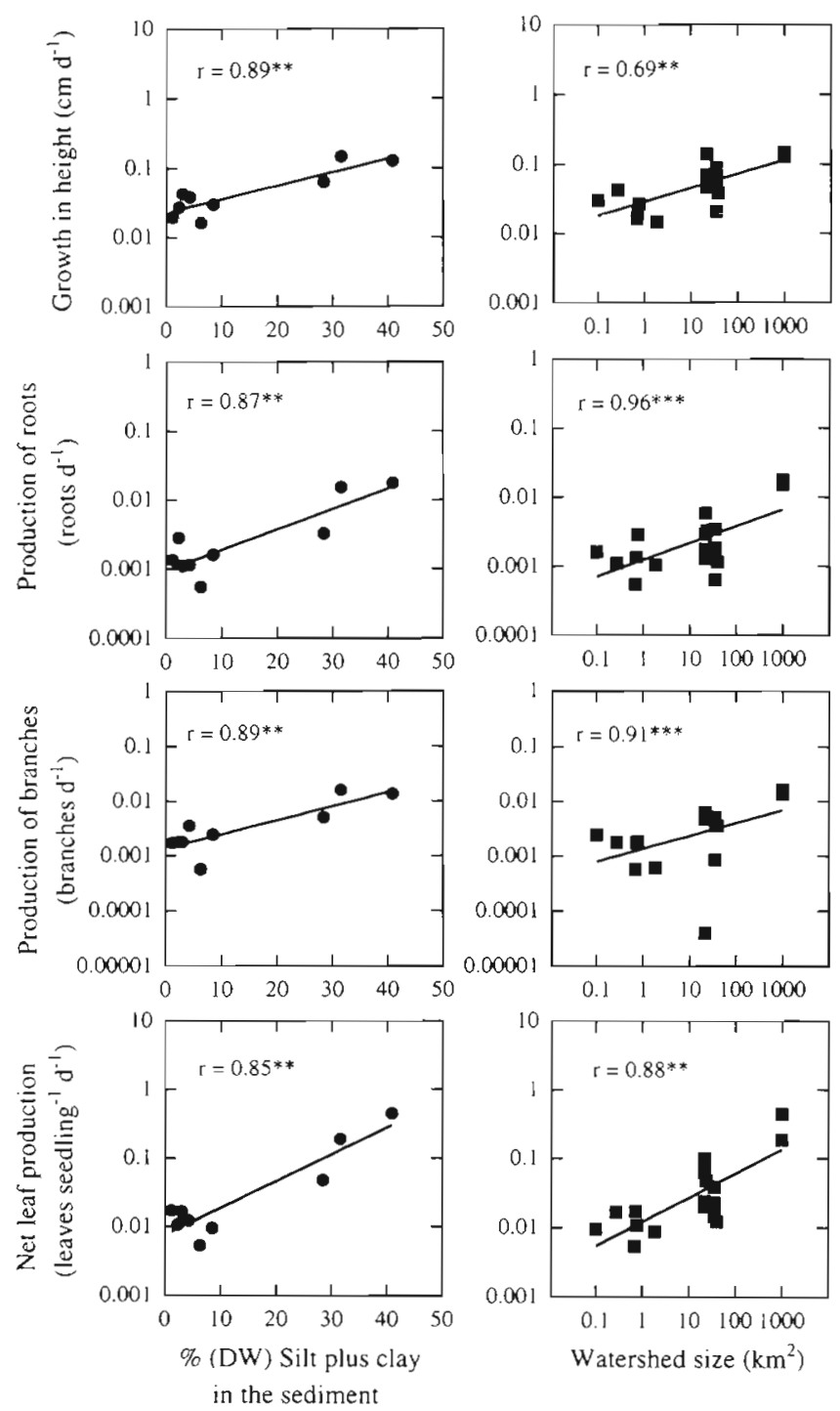

Fig. 4. Rhizophora apiculata. Relationship between the growth rate of mangrove seedlings and the silt plus clay content of the sediments, and the area drained by adjacent rivers or streams. Solid lines represent the fitted regression equations, and $r$ is the linear correlation coefficient. " $p<0.01$, $\cdots p<0.001$

and $r=0.88$ for $N$ and $P$, respectively, $p<0.005$ ). As a result, there were strong, significant positive correlations between seedling growth and nutrient concentrations in the sediment porewaters ( $r \geq 0.74$ and $r \geq 0.86$ for total inorganic nitrogen and phosphorus, respectively, $\mathrm{p}<0.005$; Fig. 3).

Leaf nitrogen and phosphorus concentrations were positively $(p<0.01)$ correlated with the percent of silt plus clay in the sediment $(r=0.89$ and $r=0.82$, respectively), and seedling growth was also positively correlated with the percent of silt plus clay in the sediment (Fig. 4, $r \geq 0.85, p<0.01$ ). The sediments with low 
nutrient concentrations and low contents of silt and clay occurred in association with rivers draining small $\left(<10 \mathrm{~km}^{2}\right)$ watersheds, whereas higher nutrient concentrations were found in the sediments containing high contents of silt and clay delivered by rivers draining large watersheds. Hence, there was a strong positive correlation ( $r=0.69, p<0.01$ ) between seedling growth and the size of the watershed drained by the rivers (Fig. 4). The relationships were, however, nonlinear and suggest a critical watershed size of about $10 \mathrm{~km}^{2}$ before the growth of Rhizophora apiculata is enhanced in the river mouth (Fig. 4).

\section{DISCUSSION}

The study clearly documents that the growth of Rhizophora apiculata seedlings living at the edge of progressing mangrove forests is directly correlated to the nutrient and silt contents within the sediments of SE Asian mangrove sites. Seedlings growing over nutrient-poor, coarse sediments had very low growth rates, to the point that their canopy only gained a couple of new leaves per year, while the highly branched canopy of seedlings growing over nutrient-rich, silty sediments gained a new leaf every other day. Experiments with fertilization suggest that the growth of mangrove trees is constrained by insufficient nutrient supplies (Onuf et al. 1977, Boto \& Wellington 1983, Feller 1995), which seems to be a general trend for tropical rainforests (Tanner et al. 1998). Twilley et al. (1986) found that tree production is higher (i.e. nutrient limitation less important) in riverine and fringe mangroves than in mangroves with slower water exchange despite the larger export of litter and nutrients from the former. For seedlings growing in the outermost fringes of mangroves, however, variable exposure may markedly change the balance between export and import of silt and nutrients, resulting in highly variable nutrient and silt contents in the sediment. It is, therefore, not a surprise that the growth of newly established seedlings in the mangrove progression zone is variable and strongly controlled by local differences in sediment nutrient content.

The relationships we found between seedling growth, foliar nutrient contents and sediment nutrient status cannot unambigously distinguish between the roles of different nutrients in the limitation of growth in Rhizophora apiculata seedlings. Growth in height and production of roots, branches and leaves were all significantly correlated to both nitrogen and phosphorus in leaves and in sediment porewater. The nitrogen concentrations in $R$ apiculata leaves (range: 0.78 to $1.66 \%$ of DW) were similar to, or in the lower end of, those found in other studies of tropical and subtropical mangroves 10.7 to $2.5 \%$ of DW; Onuf et al. 1977 , Boto \& Wellington 1983, Twilley et al. 1986, Rao et al. 1994, Feller 1995) and were also comparable to foliar nitrogen in different types of tropical rainforests 10.6 to $1.6 \%$ of DW; Tanner et al. 1998). Foliar phosphorus of $R$. apiculata seedlings $(0.06$ to $0.12 \%$ of DW) was similar to, or in the higher end of the range of, the levels usually found in both mangroves and tropical rainforests $(0.03$ to $0.11 \%$ of DW; Boto \& Wellington 1983 Feller 1995, Tanner et al. 1998), so there seems to be a tendency for younger trees growing at mangrove edges to be primarily nitrogen limited, while older mangroves growing at higher elevations tend to be more limited by phosphorus (Boto \& Wellington 1983). In our study there was a weak tendency for nitrogen to be deficient relative to phosphorus both in the leaves and within the sediments, suggesting nitrogen limitation to be most important. Nutrient addition experiments are needed to elucidate the relative roles of nitrogen, phosphorus and other essential sediment components in regulating seedling growth

The correlations presented suggest strong links between the size of the watersheds drained by the rivers where the mangrove stands develop, and sediment composition, foliar nutrient contents, and mangrove growth. Mangrove soils receive high imputs of organic matter from the mangrove itself (Boto \& Bunt 1981, Boto 1984, Twilley et al. 1986), and inorganic nutrients are imported from the sea (Kristensen et al 1995, Rivera-Monroy et al. 1995). However, a substantial fraction of the fine particulate material and the associated nutrients originate from land and are responsible for the continuous accretion of sediment, allowing sustained progression of the mangrove. The silt plus clay content of the sediments deposited at the mouths of large rivers, such as the Pak Phanang river, was very high, while sediments supporting mangroves near creeks were mainly coarse, marine carbonates. Hence, slow-growing, nutrient-deficient mangrove stands were associated with small rivers, while fastgrowing mangroves, with a more balanced nutritional status, were found in association with rivers draining watersheds larger than $10 \mathrm{~km}^{2}$.

Southeast Asian mangroves are ecologically and commercially important ecosystems, which have declined dramatically during the last 50 yr due to human exploitation (Chou 1994) While high silt loads caused by changes in land use have a negative impact on most coastal ecosystems (e.g. coral reefs and seagrass beds; Hodgson 1989. Terrados et al. 1998), they can be beneficial for mangrove progression. High silt loads in the rivers cause increased sediment accretion and thus the formation of new habitat suitable for natural mangrove colonization and continuous development of extensive mangrove forests (Panapitukkul et 
al. 1998). Our results show that increased siltation will enhance seedling growth, which likely helps the seedlings to outbalance the high mortality rates encountered by newly established unprotected seedlings (Clarke \& Myerscough 1993). In order to promote mangrove progression and compensate for earlier losses of forest area, various programmes have been initiated to protect expanding mangrove fringes and afforestation programmes have also been conducted. The nonlinear relationship between seedling growth performance and watershed size found in this study identifies mangroves next to rivers draining watersheds larger than $10 \mathrm{~km}^{2}$ as the most profitable target areas in the efforts promoting natural and artificial colonization of Rhizophora apiculata.

Acknowledgements. This research was funded by the STD-III programme of the Commission of the European Union (project TS3 ${ }^{\circ}$-CT94-0301). We thank N. Agawin for assistance in the field. This is a contribution to the LOICZ program (project no. 27), a core project of the IGBP program.

\section{LITERATURE CITED}

Aksornkoae S (1993) Ecology and management of mangrove. IUCN, Bangkok

Blasco F (1984) Climatic factors and the biology of mangrove plants. In: Snedaker SC, Snedaker JG (eds) The mangrove ecosystem: research methods. UNESCO, Paris, p 20-35

Boto KG (1984) Waterlogged saline soils. In: Snedaker SC, Snedaker JG (eds) The mangrove ecosystem: research methods. UNESCO, Paris, p 114-130

Boto KG, Bunt JS (1981) Tidal export of particulate organic matter from a northern Australian mangrove system. Estuar Coast Shelf Sci 13:247-255

Boto KG, Wellington JT (1983) Phosphorus and nitrogen nutritional status of a northern Australian mangrove forest. Mar Ecol Prog Ser 11:63-69

Chapin FS (1980) The mineral nutrition of wild plants. Annu Rev Ecol Syst 11:233-260

Chou LM (1994) Marine environmental issues of Southeast Asia: state and development. Hydrobiologia 285:139-150

Clarke PJ, Myerscough PJ (1993) The intertidal distribution of the grey mangrove Avicennia marina in southeastern Australia: the effects of physical conditions, interspecific competition and predation on propagule establishment and survival. Aust J Ecol 18:307-315

CORIN (1991) Coastal management in Pak Phanang. A historical perspective of the resources and uses. Coastal Resources Institute, Prince of Songkla University, Hat-Yai

Duarte CM, Cebrián J (1996) The fate of marine autotrophic production. Limnol Oceanogr 41:1758-1766

Duke NC, Pinzón ZS (1992) Aging Rhizophora seedlings from leaf scar nodes: a technique for studying recruitment and growth in mangrove forests. Biotropica 24:173-186

Feller IC (1995) Effects of nutrient enrichment on growth and

Editorial responsibility: Otto Kinne (Editor),

Oldendorf/Luhe, Germany herbivory of dwarf red mangrove (Rhizophora mangle). Ecol Monogr 65:477-505

Gattuso JP, Frankignoulle M, Wollast R (1998) Carbon and carbonate metabolism in coastal aquatic ecosystems. Annu Rev Ecol Syst 29:405-433

Hemminga MA, Slim FJ, Kazungu J, Ganssen GM, Nieuwenhuize J, Kruyt NM (1994) Carbon outwelling from a mangrove forest with adjacent seagrass beds and coral reefs (Gazi Bay, Kenya). Mar Ecol Prog Ser 106:291-301

Hodgson G (1989) The effects of sedimentation on IndoPacific reef corals. PhD thesis, University of Hawaii

Kristensen E, Holmer M, Banta GT, Jensen MH, Hansen K (1995) Carbon, nitrogen and sulfur cycling in sediments of the Ao Nam Bor mangrove forest, Phuket, Thailand: a review. Phuket Mar Biol Cent Res Bull 60:37-64

Mcnae W (1968) A general account of the fauna and flora of mangrove swamps and forests in the Indo-West-Pacific region. Adv Mar Biol 6:73-220

Milliman JD, Meade RH (1983) World-wide delivery of river sediment to the oceans. J Geol 91:1-21

Milliman JD, Syvitski JPM (1992) Geomorphic/tectonic control of sediment discharge to the ocean: the importance of small mountainous rivers. J Geol 100:525-544

Onuf CP, Teal JM, Valiela I (1977) Interactions of nutrients, plant growth and herbivory in a mangrove ecosystem. Ecology 58:514-526

Panapitukkul N, Duarte CM, Thampanya U, Kheowvongsri P, Srichai N, Geertz-Hansen O, Terrados J, Boromthanarat S (1998) Mangrove colonization: mangrove progression over the growing Pak Phanang (SE Thailand) mud flat. Estuar Coast Shelf Sci 47:51-61

Parsons TR, Maita Y, Lalli CM (1984) A manual of chemical and biological methods for seawater analysis. Pergamon Press, Oxford

Rao RG, Woitchik AF, Goeyens L, van Riet A, Kazungu J, Dehairs F (1994) Carbon, nitrogen contents and stable carbon isotope abundance in mangrove leaves from an east African coastal lagoon (Kenya). Aquat Bot 47:175-183

Rivera-Monroy VH, Day JW, Twilley RR, Vera-Herrera F, Coronado-Molina C (1995) Flux of nitrogen and sediment in a fringe mangrove forest in Terminos Lagoon, Mexico Estuar Coast Shelf Sci 40:139-160

Tam NFY, Li SH, Lan CY, Chen GZ, Li MS, Wong YS (1995) Nutrients and heavy metal contamination of plants and sediments in Futian mangrove forest. Hydrobiologia 295: $149-158$

Tanner EVJ, Vitousek PM, Cuevas E (1998) Experimental investigation of nutrient limitation of forest growth on wet tropical mountains. Ecology 79:10-22

Terrados J, Duarte CM, Fortes MD, Borum J, Agawin NSR, Bach S, Thampanya U, Kamp-Nielsen L, Kenworthy J, Geertz-Hansen O, Vermaat J (1998) Changes in community structure and biomass of seagrass communities along gradients of siltation in SE Asia. Estuar Coast Shelf Sci 46: $757-768$

Thom BG (1984) Coastal landforms and geomorphic processes. In: Snedaker SC, Snedaker JG (eds) The mangrove ecosystem: research methods. UNESCO, Paris, p 3-17

Twilley RR, Lugo AE, Patterson-Zucca C (1986) Litter production and turnover in basin mangrove forests in southwest Florida. Ecology 67:670-683

Submitted: May 13, 1998; Accepted: August 12, 1998

Proofs received from author(s): November 19, 1998 